\title{
Reflections of the Global Financial Crisis and the Performance of Macro-Economic Development in Kosovo
}

\author{
Msc.Venera Kelmendi \\ State University “Haxhi Zeka",Kosovo \\ venera.kelmendi@unhz.eu \\ Dr.sc.Driton Sylqa \\ State University "Haxhi Zeka",Kosovo \\ driton.sylqa@unhz.eu
}

Doi:10.5901/ajis.2013.v2n9p310

\begin{abstract}
While it is argued that the global financial crisis have not directly hit Kosovo, however, its economy has felt its indirect effects. Kosovo's economy in 2012 has been increased, but the growth rate was lower compared to previous years. The slowdown in economic progress has been caused due to global economic developments. This is because foreign direct investments and exports declined more pronounced in 2012, while imports also were characterized by slower growth. It should also be noted that increased public investments and remittances have had a tremendous contribution to economic activity. In the context of slow economic growth in recent years and fiscal pressures, Kosovo is faced with the complex challenge of unemployment, which still remains at a high level. The demand for labor is still very low and establishment of a favorable environment that would create sustainable jobs will be a challenging task that requires reforms in the economic policy. Hence, this paper addresses one of the deepest challenges of Kosovo that is domestic economic capacity to generate economic growth. By analyzing the economic factors affecting economic development, this paper identifies barriers and though discusses real opportunities for a better economic growth pattern to finally highlight the recommendations.
\end{abstract}

Keywords: financial crisis, labor market, economic growth, economic challenges, sustainable development.

\section{Introduction}

In the context of this paper will be discussed the Reflections of global financial crisis in transition economy of Kosovo. Therefore, from the outset it should be emphasized that now nearly all agree that the origins of the global financial crisis and its main cause or reason was a hard situation with the so-called "bad credit mortgage" (subprime mortgage meltdown) in the U.S. This crisis emerged in 2006, through the phenomenon of "spectacular fall-risk mortgage loans in the U.S.", a phenomenon whose consequences, after February 2007, gradually began to affect many countries and banks worldwide, and later on, in late 2007 and early 2008, to be transformed into the global financial crisis.

In the era of globalization, no country can remain isolated from global economic fluctuations. Heavy losses that suffered many major international banks will affect all countries of the world, as these financial institutions have their investment interest in almost all countries. As the result of that, Kosovo as a country in transition will be also influenced. Therefore, the focus of our research will be the reflection of the financial crisis in Kosovo's economy in transition. The word 'transition' means the period in which development must be undertaken comprehensive process, to economic changes and cultural structure of the society. Hence, as the basis of the transition are considered the market and state regulatory. The role of the state should focus on macro-economic contemporary regulation that ensures economic stability and building development policy.

These include: the stabilization of the national currency, the exchange rate, the regulation of economic relations with other developed countries, realization of regional policy, accomplishment of agrarian policy and the environmental and public finances. The state should take over the functions of social imperative, in order to more easily overcome the negative consequences in transition to the market economy. Functioning economic system itself should support democratic institutions, liberal democracy in a transparent society, as well as the internationalization of the economy and the society of Kosovo.

Moreover, the paper is focused on achieving the impact analysis of the financial crisis on the current state of the 
economy and businesses in Kosovo, as well as the presentation of research of the effects of the global financial and socio-economic development of Kosovo, and drawing conclusions on the role and importance of measuring the effects of the financial crisis on the economy of Kosovo. Therefore, the paper has been developed based on the experience and the use of materials written by renowned national and regional authors and contains the thoughts and ideas of many scientific papers and studies related to the development of the economies in transition and the effects of the global crisis. Thus, the purpose of the paper is to study and analyze the reflections on the global financial crisis in Kosovo transition economy. On the basis of this research, it will be given specific recommendations.

\section{The impact of the crisis on the real sector of the economy}

The global economy continues to face one of the largest financial crises in history. The consequences of financial crisis have been reflected in the real sector of the economy, causing one of the biggest global economic crises. In this regard, governments and central banks of the developed countries have been active in taking measures to stimulate economic activity in their countries and recently we are witnessing the first signs of an economic recovery in some economies. Kosovo's financial sector, the effect of the crisis has not been wide, characterized by a slowdown in lending by banks, while the level of sustainability of the sector was maintained despite the unfavorable circumstances in the international financial sector. Nevertheless, in the Kosovo crisis effects were more pronounced in the real sector of the economy where there is a slowdown in economic activity. ${ }^{1}$

It should be pointed out that macro-economic adjustment in the economy of Kosovo should be based on factors and strengthening institutions of the market economy, in the first place, competition, efficiency, liberalization and regulation of certain economic processes.

Competition Policy - Competition policy is the basis of any market economy. This criterion is of strategic importance to the development process in Kosovo. Competition to foreign market and domestic market will put pressure on the restructuring of the economy according to the criteria of efficiency. Taking into account the existing structure of the economy and its consequences in the social development of the population, more effective competition results can give only if combined with a long-term policy development in which is incorporated the policy of intervention. Competition in the domestic market of the Republic of Kosovo should be promoted through the regulation of natural monopolies, public property, phenomenon of bankruptcy and also financial and budgetary constraints. Foreign competition, for instance, its impact on the economy of Kosovo, will be provided primarily through liberalization policy system and relations with the other countries of the world. ${ }^{2}$

Another important point is the activities of the state reduce normality and management in the segment of cooperation with other foreign counties. This exposure will enable the establishment of new partnerships with international financial institutions, and will create the institutional prerequisites for the identification of new sources in the financing of economic development, particularly, of transition reforms. ${ }^{3}$

In other words, it should be noted that the real sector of the economy in the country in early 2011 can be considered as positive, in terms of economic activity in Kosovo. Forecasts of the International Monetary Fund (IMF) point out that real economic growth in 2011 was 5.0 percent, which represents a slight increase compared with the previous year. Real GDP growth in 2012 reached a rate of 3.8 percent, while the main carrier was public sector growth through capital investment. SMEs contributed in GDP and served as promoters of development, which are presented below.

Table 1. Contribution of enterprises in GDP

\begin{tabular}{|lccc|}
\hline Size enterprise & Number of enterprises & Currency $(€)$ & GDP(\%) \\
\hline Micro & 14,968 & $656,885,164.33$ & 16.79 \\
\hline Small & 1,210 & $667,585,914.82$ & 17.07 \\
\hline Medium & 185 & $369,455,655.16$ & 9.44 \\
\hline Large & 58 & $528,558,359.84$ & 13.51 \\
\hline Total & 16,421 & $2,222,485,094.15$ & 56.81 \\
\hline
\end{tabular}

Source: Annual report of SME, $2011^{4}$

\footnotetext{
1 UNDP Report, Development and Transitions-alb, 2011

${ }^{2}$ Statistical Report on eneteprises, alb, 2013 available at: www.ks-gov.net/esk/

${ }^{3}$ Ibid

${ }^{4} \mathrm{MTI}$, Agency for SME support, Report on SME-s, 2011, pg.24
} 
The private sector contributed to economic growth through increased consumption, while private investment was characterized by similar developments with the previous year, a positive but slowing trend. All private consumption growth, the impact of this sector on economic growth was lower than in previous years. The increase in 2012 has been significantly limited by the position of Kosovo in the foreign sector, especially, in the context of exports and foreign direct investment, and remittances were characterized by positive growth rate in Q4 2012. Price performance, as measured by the consumer price index (Consumer Price Index: CPI) during Q4 2012 was characterized by moderated inflation regardless of annual price growth reached 3.7 percent, while the average annual inflation rate for 2012 amounted to 2.5 percent. $^{5}$

The same situation, as in previous years, were the prices of imported products have had major impact on the inflation rate in Kosovo. By September 2012, import prices increased by 5.8 percent compared to September 2011, while producing prices were more stable recording an average growth rate of 0.8 percent. An encouraging fact of the economic activity in the country is the change of the weights and participating of various categories in the consumers' shopping basket, such as food products that have a very high participation. In 2012, the share of food products decreased to $37.8 \%$ of the total consumer basket than in previous years when the weight of this category was 42.7 percent. This change reflects the improvement of living standards in Kosovo considering the higher consumption of other non-food categories. ${ }^{6}$

This change in structure can also be regarded as a positive development in terms of overall price stability in the future, given that food prices are characterized by large movements, while their high weight, in general reflected price level in Kosovo. During 2012, the number of newly registered businesses increased by over 20 percent, reaching 2261 new businesses, which represents the largest number of new businesses registered in the past four years. The closure of businesses also had relatively high growth rate (16.7 percent) compared to last year with a total of 334 closed businesses. The ratio between closed and new businesses in 2012 was 11.2 percent, which is the lowest rate in the past four years. ${ }^{7}$

Based on the economic activity of registered enterprises, we note that the dominant category continues to be a trade which has a participation in new enterprises by 31.3 percent, despite the reduction in participation compared to other periods. This comes as a result of the acceleration in the growth rate for the enterprises of other sectors, particularly; more pronounced progress of enterprises in the agricultural sector amounted to 8.3 percent from 4.1 percent in the previous year, then 10.3 as processing industry and construction in 9.7 percent. $^{8}$

Enterprises registered for the activity of real estate, transport and telecommunications, and storage as well as hotel and restaurants had an impact, relatively similar to previous years. The general implications of this change in the structure of the enterprises are expected to be positive for the country's economic activity, especially, when considering the ability to add these sectors enterprises. Increasing the overall level of consumption and investment in the country is expected to be supported by public spending, which is expected to continue the trend during 2013. Inflationary pressures were present in Kosovo's economy in 2012 and still continue to be in 2013. This pressure on the general price level derived primarily from global movements of prices for food products and oil derivatives, which in Kosovo transmitted through prices of imported goods, expressed through the Import Price Index (Import Price Index: IPI). The level of correlation between the CPI and IPI is close to 0.7 , implying a very similar behavior between Kosovo consumer prices and import prices. On the other hand, producer prices have been relatively stable and their impact on the overall price level in Kosovo has been estimated as appropriate. ${ }^{9}$

It should also be emphasized that monetary policy is the main point credit for creating macro-economic stability and achieving convertibility in the conditions of the transformation and integration into the economy of Kosovo. Through monetary aggregates and other mechanisms, it will be maintained the currency stability and also, will be ensured the implementation of a political offensive development of Kosovo. This policy will be supported and implemented in terms of consolidation of trade balance, balance of payments and foreign debt servicing. The Central Bank will have a rigorous impact especially, in the segment of quantity of currency. Rigorous financial discipline and competition from abroad ensures monetary stability. This system should be compatible with the fiscal system, because it creates the preconditions

\footnotetext{
${ }^{5}$ Increased participation in the consumer basket has been noted in categories such as, household furnishings and equipment maintenance, transport, communication tools, recreation and culture, as well as restaurants and hotels.

${ }^{6}$ Report of Central Bank of Kosovo, 2011.

${ }^{7}$ Ibid

${ }^{8} \mathrm{Ibid}$

${ }^{9}$ Statistical Monthly Report, Central Bank of Kosovo, 2012.
} 
for the operation of the laws of the market economy and the establishment of 'rules of game' for all development indicators.

\section{Fiscal onsets and macro-economic policies in Kosovo}

After 1999, fiscal policy in Kosovo has been based on revenue and government spending in achieving certain economic and social goals, and to influence the macro-economic indicators. Through fiscal policy are used income and public expenditure for the implementation of economic policy. ${ }^{10}$

Budgetary and fiscal policies - fiscal and budgetary policies represent important mechanisms, they are defined as pyramid of responsibilities and authorities in the governance of financial flows in the economy of Kosovo, taking into account the requirements and strategic needs of the economy, population and the country. Fiscal policy consists of the respective shares of the government to change the level and composition (structure) of public spending and revenue from taxes and fees. ${ }^{11}$

However, during the implementation of the Kosovo budget management, special attention should be made on the elimination of sources of inflationary impacts, such as: financing deficit and budget deficit problem. Budgetary policies should be integrated and matched to fiscal policy because only then can be created equal preconditions for the realization of economic activity of economic entities. ${ }^{12}$

Price Policy - The declaration of Kosovo Independence has increased new fiscal pressures/onsets for the government at a time when the prospects for greater direct investment and exports were falling. The new economy has been left depended on public spending to mitigate the effects of the fall and to maintain indirectly a moderate level of economic growth. The budget surplus that has accumulated the Kosovo government in the past due to small or insufficient accumulative capacity, among other reasons, administrative inefficiencies that is used to increase capital spending budget which includes investments in the energy sector, transportation, agriculture, construction of schools, and other infrastructure improvements.

As a new state, Kosovo has also other expenses such as the full consolidation of the Ministry of Foreign Affairs, including new embassies, security and minority programs, etc. The focus on financing some of the new programs, are expected to push the budget balance in deficit. Annual budget deficit of 2008 was lower, while the 2009 budget deficit is expected to reach about 7\% of GDP. Despite the prescription of the International Monetary Fund (IMF), the government decided to increase the salaries of public employees by $10 \%$ from January $2009 .{ }^{13}$

While this increase of salary can improve the quality of their work, promote the integrity of government, etc. It does not warn the achievement of sustainable fiscal framework, in particular when considering the recent capital expenditures and problems with high quasi-fiscal deficit of the energy sector. Lower stimulation for tax evasion can improve their collection, however, since this tax reduction policy went into effect in early 2009, when public investment was already low, the effects of this tax base and fiscal reform revenues are not entirely clear. Government projected revenue figures suggest a substantial financial vacuum in the next few years in order to meet the objectives of economic growth with government capital expenditures. Ministry of Economy and Finance has planned a total financing gap of approximately 300 million Euro (2009-2012) with donor contributions or borrowing that are expected to fill this gap. ${ }^{14}$

Thinking about the precariousness of the fiscal deficit and high projected costs, is important to remember, that one of the most impacted features of the Kosovo economy is Euro - fiscal policy instrument for intervention. While fiscal pressures, outlined above are not atypical for many countries in transition, not all developing countries are limited into the fiscal domain. For Kosovo, it has some substantial political implications. Against the fact that the effects of the recent global economic crisis were minimal in Kosovo, some important lessons for the fiscal policy to respond to future economic shocks are (i) to improve the quality of existing savings and reduce non-essential spending to ensure solvency of the government to protect the real economy from future external/foreign shocks (ii) to increase the minimum stabilization fund reserves to reflect the size of the economy (iii) to gain benefits policy-making by developing a government debt market as an alternative instrument to provide more flexibility for the government. ${ }^{15}$

\footnotetext{
${ }^{10}$ Komoni, Sabahudin, "Public Finances", alb., pg.129, Prishtinë, 2008.

${ }^{11}$ Merovci Safet, "Financial Markets", alb., pg.127, Prishtinë, 2008.

12 UNDP Report, Development and Transition, alb, 2011

${ }^{13}$ Central Bank of Kosovo, Monthly Statistical Report, "CASH Report", 2009.

${ }^{14} \mathrm{Ibid}$

${ }^{15} \mathrm{lbid}$
} 


\section{The impact of the crisis on the financial sector in Kosovo}

It can be argued that the overall slowdown of activity in the economy of Kosovo was reflected in the financial sector. In Q4 2012 Kosovo's financial sector recorded weaker results compared with the previous year. At the end of 2012, the assets of the banking system amounted to 2.8 billion Euro, an increase of 6.8 percent, which represents an increase lower compared to the same period last year when it was registered an increase of 7.9 percent. While the banking sector continued to have a high level of stability despite negative developments in the international financial sector as a result of financial crisis. ${ }^{16}$

Although, deposit growth rate was higher than the rate of credit growth, banks proved to be more cautious in lending to the economy. In Q4 deposits of the banking system amounted to 2.27 billion Euros, an increase of 3.8 percent compared with Q3. Recorded an increase of 0.2 percent loans reached 1.76 billion Euros, which represents a slight increase compared to Q3 when the increase was negative. Throughout the year 2012, banks were lending oriented households compared to lending to enterprises, where it can be seen that lending to enterprises recorded an annual growth of just 3 percent, compared with annual increase of 6.2 recorded the household sector. Statistics reported by the banks rely on the result of a survey conducted by the CBK of banks operating in Kosovo. Based on the survey results, during the year 2012, it appears that banks reported reduced demand for loans by enterprises, and increasing demand from households. Also, banks reported a 'buckle' of standards and criteria applied in the lending process for both categories. Furthermore, intended for trade loans continue to dominate and be one of the highest increasing categories. At the end of 2012, loans to the retail sector reached a value of 635.3 million compared to 606.2 million Euros in the same period last year. While the agricultural sector, although there is an almost equal participation in the trade sector composition of GDP (in 2011, agriculture accounted for 14.1 percent and trade 14.5 percent of GDP), compared to agriculture lending trade sector continues to be much lower. However, the highest number of newly registered enterprises in the agricultural sector, as well as increased agricultural subsidies by the government, could improve the prospects of this sector, making this sector to be more attractive to both lending by the banking sector. ${ }^{17}$

The performance of the banking system in Kosovo continues to be positive, but there is a lower profitability of indicators compared with the previous period. Moreover, it may be noted that the return on average assets (ROA) and Return on Average Equity (ROAE) declined. Total profit of the banking system in 2012 almost halved to 19.2 million Euros from 36.6 million Euros as at the end of 2011. Out of a total of 9 banks operating in Kosovo, 5 reported a positive net profit, while 4 reported negative net profit. Major impact in reducing the profitability of the banking system was the deterioration of the credit portfolio was reflected in increased costs to cover losses from non-performing loans with provisions. For this period, the ratio of non-performing loans (Non- Performing Loans: NPL) and total loans amounted to 7.5 percent from 7.0 in September 2012. Despite the increased level of non-performing loans, banks continue to be conservative in maintaining coverage NPL by provisions for loan losses. In December 2012, the index stood at 112.7 percent. ${ }^{18}$

Regarding the level of liquidity in the banking system, the banks proved to be quite careful to keep reserve rate at a higher level than the level required by the Central Bank. Also, satisfactory liquidity situation determined by the ratio of loans to deposits of 77.4 percent, and assets 'broad' in relation to the total liquid assets of 32.5 per cent. Kosovo's banking system remains well capitalized despite the slight fall Capital Adequacy Ratio (Capital Adequacy Ratio: CAR) 3, which was decreased from 18.8 percent in December 2011, at 17.9 percent in December 2012. In late 2012, the total capital of the banking system amounted to 310.9 million Euros, marking an annual increase of 3.7 percent, while the riskweighted assets (Risk Weighted Assets: RWA) increased by 1.7 per cent, standing at 1.73 billion Euros. During 2012, the banking system was added another bank. It should also be pointed out that in November; the Central Bank of the Republic of Kosovo approved a license for a new bank with Turkish capital, "Turkie Is Bankasi AS" which raised the total number of banks in Kosovo to nine. ${ }^{19}$

With all the constant development, the function of commercial banks operating in Kosovo continues to be essential, mostly concentrated in lending to the local economy, being funded by deposits collected within the country. This has

\footnotetext{
${ }^{16}$ Luboteni, Gazmend, "Bank Management", pg.43, Prishtinë, 2008.

${ }^{17}$ Central Bank of Kosovo, Monthly Statistical Bulletin, 2011.

${ }^{18}$ Central Bank of Kosovo, Financial Stability Report, No. 3., 2012.

19 Ibid
} 
meant that commercial banks operating in Kosovo do not have high levels of exposure to the external/foreign sector, and financing through deposits collected in the country has made the level of lending in Kosovo should not be dependent on the supply and cost of funds in the foreign sector. ${ }^{20}$

Therefore, the most important development of the current banking crisis is the transmission of the crisis to the rest of the economy and its interaction with the general economic crisis arising currently. Additionally, the most obvious issue here is the beginning of the recession. The main reason for the recession is the dependence of consumer demand in particular business investment but also high levels of debt over the last two decades. Considering the current developments can be said that the banking sector is shown to be 'immune' to the global financial crisis. However, due to the extent of the ongoing economic crisis, it is expected a slowdown in economic activity in Kosovo, with possible negative implications for performance of banking sector. Hence, while respecting the principles of lending, the extension of credit at this time, while respecting the principles of good lending, is a very important factor to stimulate economic activity and to avoid some extent negative effects of the crisis.

\subsection{Security companies}

Based on the latest available data of insurance companies, it is suggested the expansion of activity in this sector. In late 2012, the value of premiums received amounted to 81.5 million euro, recording an annual increase of 4.4 percent. Meanwhile, during the same period last year, claims paid amounted to 30.6 million Euros, marking an annual increase of 25.1 percent. $^{21}$

\subsection{Pension funds}

In 2012, Kosovo Pension Savings Trust (KPST) has recorded a positive performance, compared with the previous year. Total value of fund assets under management amounted to EUR 739.8 million (December 2011, 593.3 million), while the stock price was 1,117 euro per share (December 2011, 1,034 euro per share). Total return on investments made in 2012 was 8 per cent, or 54.2 million Euros. ${ }^{22}$

\subsection{Microfinance institutions}

During 2012, the performance of MFIs decreased in all reported indicators. Total loans issued by MFIs decreased continuously in 2012, where in December amounted to 98.8 million Euros from 104.7 million as it was in December 2011 (an annual decline of 5.6 percent). Despite the high rates of interest during this period, IMF-t recorded losses of $\$ 4.5$ million (in 2011 recorded a profit in the amount of 0.9 million Euros). ${ }^{23}$

\subsection{Capital market}

Also, market treasury bills of the 'Government of Kosovo' that began in January 2012, represents the only component within the equity market in country. During Q4 2012 were held 3 auctions, which have had offered the amount of 10 million Euros with a maturity of 91 days. Of these amounts, 10 percent of the total bids were not competitive, while the rest were competitive. Bidding primary stakeholders in each round exceeded the amount offered by the Treasury an average of 2.1 times during Q4 2012.24

Auctions current interest rate is characterized by a steady decline reaching 1.08 percent in December, the lowest level of all year. Overcoming treasury supply of primary indicators bidding for 2.1 times, on the other hand, continued decline in the rate of interest in each auction, which can be considered as important reflection on the financial sector, fiscal and real economy. ${ }^{25}$

\footnotetext{
20 UNDP Report, Development and Transition, alb, 2011.

${ }^{21}$ Producer Price Index, Government of Kosovo, accessed in February, 2013.

${ }^{22}$ CBK, Balance Report Payments, 2012.

${ }^{23} \mathrm{Ibid}$

${ }^{24}$ CBK, Monthly Statistical Bulletin, 2012

${ }^{25}$ CBK, Balance Report Payments, 2012
} 
From the perspective of the financial sector, higher bidding reflects satisfactory liquidity in the banking system and banks' tendency to use free tools also better diversify their investment portfolio. In the context of the fiscal sector, the decline continued interest rate reflects the confidence of financial institutions in the government's fiscal stability of the country. Real sector, bidding banks with low interest rate reflects the lack of absorptive capacity and private sector investment projects. This is because the banks continue to have the capacity to invest in treasury bills with a relatively low rate of interest against lending to the economy, which is characterized by a relatively high rate of interest.

\section{The impact of the crisis on the foreign sector}

Under the current arrangement as euro economy, Kosovo has the Central Bank for conducting monetary policy and absorbing the effects of foreign shocks, which means setting the nominal interest rate to stimulate general demand. Once the effects of the recent global crisis has been minimal for Kosovo, this does not mean that it will continue to be the same situation in the future, especially, since Kosovo aims to increase the entry of foreign capital and become more integrated into global trade. An effective alternative to the lack of flexibility is to reduce non-essential spending and focus more on the quality of spending, building stabilization potentiality or resources and development of government securities market, at the appropriate time. ${ }^{26}$

According to some trade statistics that are published by the CBK, shows that, since September 2012 have undergone methodological change as a result of the exclusion of statistics for electricity trade in total trade activity. However, with the available data, the current account deficit in Q4 2012 amounted to 574.1 million Euros as a result of imports valued at 641.2 and exports of 67.1 million Euros. However, despite unusually high energy trade statistics, current balance of payment during Q4 2012 has been decreased by about 10 percent, which simultaneously represents significant decline of the post-war period. By the end of 2012, exports of goods amounted to 269.3 million Euros, while imports of goods amounted to EUR 2.5 billion, making the coverage of imports with exports to reach a rate of 10.8 percent. 27

Foreign trade statistics consistently show high trade deficit, exports of products and services are estimated to be $8.2 \%$ of imports during the last ten years. Whilst, according to yet uncompleted official data by the same source, exports in 2012 covered imports by $10.8 \%$ only. 28

\begin{tabular}{ccccc}
\hline Year & Exports & Imports & $\begin{array}{c}\text { Balance of } \\
\text { payment }\end{array}$ & Export /Import \\
\hline $\mathbf{2 0 0 1}$ & 10,559 & 684,5 & $-673,941$ & $1.5 \%$ \\
$\mathbf{2 0 0 2}$ & 27,599 & 854,758 & $-827,159$ & $3.2 \%$ \\
$\mathbf{2 0 0 3}$ & 35,621 & 973,265 & $-937,644$ & $3.7 \%$ \\
$\mathbf{2 0 0 4}$ & 56,567 & $1,063,347$ & $-1,006,780$ & $5.3 \%$ \\
$\mathbf{2 0 0 5}$ & 56,283 & $1,157,492$ & $-1,101,209$ & $4.9 \%$ \\
$\mathbf{2 0 0 6}$ & 110,774 & $1,305,879$ & $-1,195,105$ & $8.5 \%$ \\
$\mathbf{2 0 0 7}$ & 165,112 & $1,576,186$ & $-1,411,074$ & $10.5 \%$ \\
$\mathbf{2 0 0 8}$ & 196,463 & $1,928,236$ & $-1,729,773$ & $10.3 \%$ \\
$\mathbf{2 0 0 9}$ & 165,328 & $1,935,541$ & $-1,770,213$ & $8.5 \%$ \\
$\mathbf{2 0 1 0}$ & 294,031 & $2,139,534$ & $-1,845,503$ & $13.7 \%$ \\
$\mathbf{2 0 1 1}$ & 313,106 & $2,479,611$ & $-2,166,505$ & $12.6 \%$ \\
$\mathbf{2 0 1 2}$ & $269,000^{*}$ & $2,489,000$ & $-2,220,000^{*}$ & $10.8 \%{ }^{*}$ \\
\hline
\end{tabular}

Source: Statistical Agency of Kosovo (2013). *Uncompleted data; (f) Forecast; Source: CBK, KAS and IMF (2013)

Also, remittances as one of the most important components of the balance of payments, in September 2012 amounted to 436.7 million Euros compared to September 2011 represents an increase of 2.0 percent. Increased remittances in Kosovo is considered to have been consistently anti-cyclical behavior when one considers that the opposite behavior with other macroeconomic indicators most of which during this period was characterized by slower or negative developments. As another component of great importance in the context of the balance of payments, is also FDI, which until September

\footnotetext{
26 UNDP Report, 2012.

${ }^{27}$ CBK, Yearly Report, 2013.

${ }^{28}$ Foreign Trade Statistics, Statistical Agency of Kosovo, 2012.
} 
2012 reached a value of 167.0 million Euros, according to official data. FDI flow to Kosovo has been declining from year to year given unfavorable business climate around the globe. Today, Kosovo is facing fierce regional competition in attracting more FDI. According to the World Bank statistics, there has been a 30\% decrease in FDI flows from 2007 to 2010 in Kosovo, or from $\$ 603,224,093$ to $\$ 413,401,759$. This trend continued throughout last year. ${ }^{29}$

However, compared with the same period of the previous year, FDI decreased substantially from 41.3 percent. The decline of FDI in addition to the deterioration of the overall economic environment in Europe, mostly addressed to the slowdown of the privatization process in 2012.

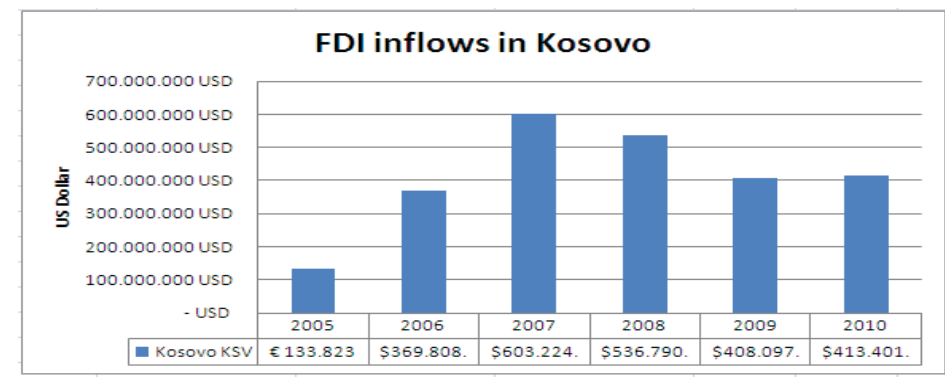

Source: World Bank, april 2012

Moreover, it's worth mentioning that in addition to the effect of the downturn which affects employment generation in the country, in 2012, changing the structure of FDI is not in favor of employment growth regardless of the sectors that mostly generate FDI sectors that do not have large space in the increasing of employment. This is because real estate has doubled in FDI participation, and primarily consists of the purchase of real estate by non-residents in Kosovo. Therefore, in order for the country progress, Kosovo needs to assure a more suitable "climate" for FDI, offering complete security, developing policy, and also decreasing taxes.

\section{Conclusion and Recommendations}

Kosovo as a state in transition, still faces the effects of the global financial crisis, and also will be facing them in 2013. While it is argued that the global financial crisis has not directly hit Kosovo, its economy has felt its indirect effects. The effects of the financial crisis in our country can have effects on remittances. It is also worth mentioning that donor countries have been reluctant to increase their support for Kosovo because of internal problems; dramatic increase in unemployment in Europe and in the U.S., has affected the Kosovars living abroad. Subsequent decrease in remittances from Kosovars living outside the country is likely to have a negative impact on the economy of Kosovo in general. The money send from abroad in Kosovo are as the only source of income for many families, since unemployment remains yet at a very high level.

Kosovo also might face negative effects in terms of foreign investment in our country, as many powerful economies are afraid to enter a phase of recession due to the financial crisis. Therefore, particular problem in the economy but also in the country's financial system affects the reduction of foreign investment in Kosovo, as well as Kosovo's trade deficit and many other factors that are the cause of the crisis and are isolated many transition countries such as Kosovo. Moreover, the trade deficit is still very high with only $10 \%$ of exports covering imports is also affecting the economy of Kosovo.

Whilst, Euro currency has offered the financial sector an extra degree of credibility. It has also eliminated the possibility of the bankrupt of banks and speculative attacks on the domestic currency. With the euro currency, Kosovo has passed the risk of incongruity of currency debt, which provides useful flexibility in the future. It should also be pointed out that the fiscal policies in Kosovo, despite the fact that the effects of the recent global economic crisis were minimal in Kosovo, important lessons for fiscal policy to respond to future economic shocks are: 
(i) to improve the quality of savings existing and reduce non-essential spending to ensure the solvency of the government to protect the real economy from future foreign shocks; (ii) to increase the minimum stabilization fund reserves to reflect the size of the economy; (iii) to gain benefits policy-making by developing a government debt market as an alternative instrument to provide more flexibility for the government.

In our opinion, a better political consensus should be available for resolving the financial crisis. We have thought that the solution to the crisis is more of an art than a science. Solving the crisis requires authorities to take into account not only the economic, but also political and social environment. The solution should not be based on ideological dogma of any kind, but should be based on real politics. Kosovo should be directed to build economic system according to the requirements of an economy open to European and world market. The economic system that creates a suitable environment for the integration of the economy on the region and beyond it, stimulating economic cooperation and encourage joint investments with foreign partners would need to be enhanced. The role of government should be focused on contemporary macro-economic regulation, which include: the stabilization of the currency, the exchange rate, regulation of economic relations with the world, the establishment of regional policy, the establishment of agrarian policy, the environmental and public finances as well.

Finally, the Republic of Kosovo is facing with many transition challenges, therefore the government has a lot of work to do. It is needed a greater commitment of all relevant factors such as: the Government, the civil society and businesses to consolidate in macro and micro economic terms. It should take the lead of pushing forward the process of economic development and must take responsibilities. In this process, it needs strong international support, mainly from the EU. Government of Kosovo and the international community led by the EU should work together to ensure that limited funds are best utilized availability having more focus, better delivery and better absorption. If Kosovo sooner pretends to be part of EU, the EU in Kosovo should play a more meaningful and important role.

\section{References}

CBK, Balance Report Payments, 2012.

CBK, Monthly Statistical Bulletin, 2012

CBK, Yearly Report, 2013.

Central Bank of Kosovo, Financial Stability Report, No. 3., 2012.

Central Bank of Kosovo, Monthly Statistical Bulletin, 2011.

Central Bank of Kosovo, Monthly Statistical Report, "CASH Report", 2009.

Central Bank of Kosovo, Monthly Statistical Report, 2012.

Foreign Trade Statistics, Statistical Agency of Kosovo, 2012.

Komoni, Sabahudin, "Public Finances", alb., Prishtinë, 2008.

Luboteni, Gazmend, "Bank Management", Prishtinë, 2008.

Merovci Safet, "Financial Markets", alb., Prishtinë, 2008.

MTI, Agency for SME support, Report on SME-s, 2011.

Producer Price Index, Government of Kosovo, accessed in February, 2013.

Statistical Report on enterprises, alb, 2013 available at: www.ks-gov.net/esk/

Sylqa, D., Kelmendi, V., "The economic policy trends in kosovo, challenges and growth", Third International Conference, Kosovo, 2013.

UNDP Report, Development and Transition, alb, 2011. 